\title{
Herpetiform dermatitis (Clinical case)
}

\author{
Dermatite herpetiforme (Caso clínico) \\ Bruno Sousa ${ }^{1,2,3}$, Nelson Tavares ${ }^{1,2^{*}}$
}

${ }^{1}$ School of Sciences and Health Technologies, Universidade Lusófona de Humanidades e Tecnologias, Lisboa, Portugal

${ }^{2}$ CBIOS - Universidade Lusófona's Research Center for Biosciences and Health Technologies, Lisboa, Portugal

${ }^{3}$ Health Service of Autonomous Region of Madeira, Madeira, Portugal

* corresponding author: nelson.tavares@ulusofona.pt

Received / Recebido: 03/12/2020

Accepted / Aceite: 26/02/2021

Electronic Edition: www.alies.pt

A 44-year-old female teacher was referred to the Nutrition Consultation for Dermatology for a gluten-free diet. She had experienced a cluster of red and intensely itchy blisters at the cutaneous level for approximately six months. After a study by Dermatology, a herpetiform dermatitis was diagnosed. While waiting for the Nutrition Consultation, she removed the gluten from her diet and saw improvements in symptoms. Awaiting Gastroenterology Consultation.

Keywords: Duhring Brocq disease; dermatitis; herpetiformis; gluten-free diet

\section{Anthropometric assessment}

Weight: $59.9 \mathrm{~kg}$

Height: $164 \mathrm{~cm}$

BMI: $22.3 \mathrm{~kg} / \mathrm{m}^{2}$

Usual weight: $62 \mathrm{~kg}$

Body composition assessment (TANITA TBF 300 ${ }^{\circledR}$ )

Body fat: $28.9 \%$

Fat mass: $17.3 \mathrm{~kg}$

Non-fat mass: $42.6 \mathrm{~kg}$

Total body water: $31.2 \mathrm{~kg}$
Uma mulher de 44 anos, professora, foi encaminhada à Consulta de Nutrição para Dermatologia para dieta sem glúten. Apresenta a nível cutâneo, há cerca de 6 meses, um aglomerado de bolhas avermelhadas e intensamente pruriginosas. Após estudo pela Dermatologia foi diagnosticado uma Dermatite Herpetiforme. Enquanto aguardava pela Consulta de Nutrição retirou o glúten da alimentação e verificou melhorias na sintomatologia. Aguarda Consulta de Gastrenterologia.

Palavras-chave: Doença de Duhring Brocq ; dermatite; herpetiforme; dieta isenta de glúten

\section{Avaliação antropométrica}

Peso: $59,9 \mathrm{~kg}$

Estatura: $164 \mathrm{~cm}$

IMC: $22,3 \mathrm{~kg} / \mathrm{m}^{2}$

Peso habitual: $62 \mathrm{~kg}$

Avaliação da composição corporal (TANITA TBF 300 ${ }^{\circledR}$ ) Gordura corporal: $28,9 \%$

Massa gorda: $17,3 \mathrm{~kg}$ Massa isenta de gordura: $42,6 \mathrm{~kg}$ Água corporal total: $31,2 \mathrm{~kg}$ 


\section{Analytical Parameters}

\section{Hematology}

Red blood cells: $4.54 \times 10^{12} / \mathrm{L}(4.50-6.40)$

Hemoglobin: 14.2 g/dL (13.0-16.5)

Hematocrit: $40.9 \%$ (39.8-52.0)

White blood cells: $5.64 \times 10^{9} / \mathrm{L}(4.0-10.0)$

Neutrophils: $4.25 \times 10^{9} / \mathrm{L}(1.5-8.0)$

Eosinophils: $0.1 \times 10^{9} / \mathrm{L}(<0.5)$

Basophils: $0.1 \times 10^{9} / \mathrm{L}(<0.3)$

Lymphocytes: $1.63 \times 10^{9} / \mathrm{L}(0.8-4.0)$

Monocytes: $0.4 \times 10^{9} / \mathrm{L}(<1.2)$

Sedimentation speed: $7 \mathrm{~mm} / \mathrm{h}$ (up to 20 )

\section{Biochemistry}

Glucose: 97 mg/dL (67 - 110)

Hemoglobin HbA1c assay: 5.2\% (3.8-5.8)

Urea: $19 \mathrm{mg} / \mathrm{dL}(10$ - 55)

Creatinine: $0.7 \mathrm{mg} / \mathrm{dL}(0.6-1.4)$

Uric acid: $4.6 \mathrm{mg} / \mathrm{dl}(2.4-5.7)$

Glutamic-oxalacetic transamines: $16 \mathrm{U} / \mathrm{L}(10$ - 35)

Glutamic-pyruvic transamines: 12 U/L (10 - 44)

Glutamyltransferase Range: 10 U/L (5 - 38)

C-reactive protein: negative

Total Cholesterol: $184 \mathrm{mg} / \mathrm{dl}$ (100-190)

HDL cholesterol: $54 \mathrm{mg} / \mathrm{dl}(>45)$

LDL cholesterol: $115 \mathrm{mg} / \mathrm{dl}$ (35-110)

Triglycerides: $75 \mathrm{mg} / \mathrm{dl}$ (5-184)

Calcium: $9.6 \mathrm{mg} / \mathrm{dl}(8.4-10.4)$

Phosphorus: $3.2 \mathrm{mg} / \mathrm{dl}(2.4-4.0)$

Magnesium: $1.9 \mathrm{mg} / \mathrm{dl}(1.6-2.6)$

Total vitamin D: $48.0 \mathrm{ng} / \mathrm{ml}(>20)$

Folic acid: $11.54 \mathrm{ng} / \mathrm{ml}(3-17)$

Vitamin B12: 294.10 pg/ml (200-950)

Ferritin: $121.5 \mathrm{ng} / \mathrm{ml}(9-120)$

TSH - Thyrostimulating Hormone: 1.48 UI/L (0.5-6)

T4 - Tetraiodothyronine: $11.32 \mu \mathrm{g} / \mathrm{dl}$ (4-13)

Gliadin - Ac. IgA: 1.4 AU/ml $(<10)$

Gliadin - Ac. IgG: $<0.6 \mathrm{AU} / \mathrm{ml}(<10)$

Tissue Transglutaminase - Ac. IgA: $0.3 \mathrm{AU} / \mathrm{ml}(<10)$

Tissue Transglutaminase - Ac. IgG: $<0.4$ AUml $(<10)$

S. cerevisae - ASCA, Ac. IgG: $2 \mathrm{U} / \mathrm{ml}(<10)$

Calprotectin: $37 \mathrm{mg} / \mathrm{kg}$ (up to 50 )

\section{Parâmetros analíticos}

\section{Hematologia}

Glóbulos vermelhos: 4.54 x10 12/L (4.50 - 6.40)

Hemoglobina: 14.2 g/dL (13.0-16.5)

Hematócrito: $40.9 \%$ (39.8-52.0)

Glóbulos brancos: $5.64 \times 10^{9} / \mathrm{L}(4.0-10.0)$

Neutrófilos: $4.25 \times 10^{9} / \mathrm{L}(1.5-8.0)$

Eosinófilos: $0.1 \times 10^{9} / \mathrm{L}(<0.5)$

Basófilos: $0.1 \times 10^{9} / \mathrm{L}(<0.3)$

Linfócitos: $1.63 \times 10^{9} / \mathrm{L}(0.8-4.0)$

Monócitos: $0.4 \times 10^{9} / \mathrm{L}(<1.2)$

Velocidade de sedimentação: $7 \mathrm{~mm} / \mathrm{h}$ (até 20)

\section{Bioquímica}

Glicose: $97 \mathrm{mg} / \mathrm{dL}(67-110)$

Doseamento da hemoglobina HbA1c: 5,2\% $(3,8-5,8)$

Ureia: $19 \mathrm{mg} / \mathrm{dL}(10-55)$

Creatinina: $0.7 \mathrm{mg} / \mathrm{dL}(0,6-1,4)$

Ácido úrico: $4.6 \mathrm{mg} / \mathrm{dl}(2,4-5,7)$

Transaminase Glutâmico-oxalacética: 16 U/L (10 - 35)

Transaminase Glutâmico-pirúvica: 12 U/L (10 - 44)

Gama Glutamiltransferase: 10 U/L (5 - 38)

Proteína $\mathrm{C}$ reativa: negativa

Colesterol Total: $184 \mathrm{mg} / \mathrm{dl}(100-190)$

Colesterol HDL: $54 \mathrm{mg} / \mathrm{dl}(>45)$

Colesterol LDL: $115 \mathrm{mg} / \mathrm{dl}$ (35-110)

Triglicéridos: 75 mg/dl (5-184)

Cálcio: $9,6 \mathrm{mg} / \mathrm{dl}(8,4-10,4)$

Fósforo: $3,2 \mathrm{mg} / \mathrm{dl}(2,4-4,0)$

Magnésio: $1,9 \mathrm{mg} / \mathrm{dl}(1,6-2,6)$

Vitamina D total: $48,0 \mathrm{ng} / \mathrm{ml}(>20)$

Ácido fólico: $11,54 \mathrm{ng} / \mathrm{ml}$ (3-17)

Vitamina B12: 294,10 pg/ml (200-950)

Ferritina: 121,5 ng/ml (9-120)

TSH - Hormona Tirostimulante:1.48 UI/L (0,5-6)

T4 - Tetraiodotironina: $11,32 \mu \mathrm{g} / \mathrm{dl}$ (4-13)

Gliadina - Ac. IgA: 1,4 UA/ml $(<10)$

Gliadina - Ac. IgG: $<0,6 \mathrm{UA} / \mathrm{ml}(<10)$

Transglutaminase Tecidular-Ac. IgA: $0,3 \mathrm{UA} / \mathrm{ml}(<10)$

Transglutaminase Tecidular-Ac. IgG: $<0,4 \mathrm{UA} / \mathrm{ml}(<10)$

S. cerevisae - ASCA, Ac. IgG: $2 \mathrm{U} / \mathrm{ml}(<10)$

Calprotectina: $37 \mathrm{mg} / \mathrm{kg}$ (até 50) 


\section{Clinical evaluation}

\section{Personal background}

- Allergic rhinitis

- Asthma

\section{Complementary diagnostic tests}

Biopsy of skin lesion on the scalp:

The presence of neutrophils, some eosinophils, and nuclear debris along the dermoepidermal junction, are compatible with the diagnosis of Dermatitis herpetiformis.

Intestinal transit: regular

\section{Eating habits}

Wake up at 7 am

Breakfast: 7:30 am

1 cup of unsweetened coffee +1 gluten-free bread with cheese

Morning snack: 10 am

1 piece of fruit

Lunch: $1 \mathrm{pm}$

Dish: $1 / 4$ of rice / potato dish + meat or fish $(120 \mathrm{~g})+$ varied vegetables $(150 \mathrm{~g})$ seasoned with olive oil

Dessert: 1 piece of fruit

Afternoon snack: 4:30 pm

1 cup of unsweetened coffee +1 gluten-free bread with cheese

Dinner: 8 pm

Dish: $1 / 4$ of rice / potato dish + meat or fish $(120 \mathrm{~g})+$ varied vegetables $(150 \mathrm{~g})$ seasoned with olive oil

Go to bed at 10:30 pm

Water / tea consumption: about 1.5 liters of water per day

\section{Environment, behavior and social}

She lives with her husband and two teenage children. In view of the pandemic situation, it is limited to her family and professional life, with no social activities. She states that the current situation has also conditioned her physical exercise routine.

\section{Avaliação clínica}

Antecedentes pessoais:

- Rinite alérgica

- Asma

Exames complementares de diagnóstico

Biopsia de lesão cutânea do couro cabeludo:

A presença de neutrófilos, alguns eosinófilos e detritos nucleares, ao longo da junção dermoepidérmica, são compatíveis com o diagnóstico de Dermatite herpetiforme.

Trânsito intestinal: regular

\section{Hábitos alimentares}

Acorda às $7 \mathrm{~h}$

Pequeno-almoço: $7 \mathrm{~h} 30$

1 chávena de café sem açúcar +1 pão sem glúten com queijo

Lanche da manhã: $10 \mathrm{~h}$

1 peça de fruta

Almoço: $13 \mathrm{~h}$

Prato: $1 / 4$ do prato de arroz / batata + carne ou peixe $(120 \mathrm{~g})+$ verdura variada $(150 \mathrm{~g})$ temperada com azeite Sobremesa: 1 peça de fruta

Lanche da tarde: $16 \mathrm{~h} 30$

1 chávena de café sem açúcar +1 pão sem glúten com queijo

Jantar: $20 \mathrm{~h}$

Prato: $1 / 4$ do prato de arroz/batata + carne ou peixe (120 g) + verdura variada $(150 \mathrm{~g})$ temperada com azeite

Deita-se às $22 \mathrm{~h} 30$

Consumo de água/chá: cerca de 1,5 litros de água por dia

\section{Ambiente, comportamento e social}

Vive com o marido e com os dois filhos adolescentes. Face à situação pandémica, limita-se à sua vida familiar e profissional, não existindo atividades sociais. Refere que a situação atual também tem condicionado a sua prática de exercício físico. 


\section{Questions}

1. What is herpetiform dermatitis?

2. Do patients with herpetiform dermatitis have any enteropathy?

3. Is herpetiform dermatitis not related to herpesvirus?

4. What is the appropriate treatment for this pathology in addition to the pharmacological approach?

5. What are the consequences of adherence to a glutenfree diet by patients with herpetiform dermatitis?

\section{Authors Contributions Statement}

The contribution to the preparation of this Case Study was identical for both authors.

\section{Acknowledgements}

The authors wish to express their thanks to the patient who allowed the elaboration of the case study.

\section{Conflict of Interests}

The authors declare there are no financial and personal relationships that could present a potential conflict of interests.

\section{Questões}

1. O que é a dermatite herpetiforme?

2. Os pacientes com dermatite herpetiforme apresentam alguma enteropatia?

3. A dermatite herpetiforme não está relacionada com o herpesvírus?

4. Qual o tratamento adequado a esta patologia para além da abordagem farmacológica?

5. Quais as consequências da adesão a uma dieta sem glúten por pacientes com dermatite herpetiforme?

\section{Declaração sobre as contribuições do autor}

A contribuição na preparação deste Caso de Estudo foi idêntica para os dois autores.

\section{Agradecimentos}

Os autores desejam expressar os seus agradecimentos à paciente que permitiu a elaboração desde e caso de estudo.

\section{Conflito de Interesses}

Os autores declaram que não há relações financeiras e pessoais que possam representar um potencial conflito de interesses. 


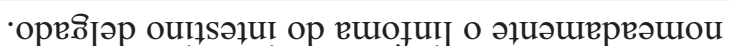

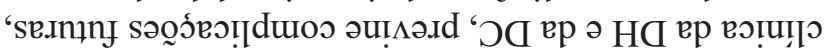

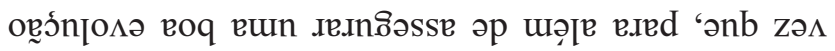

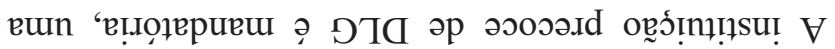

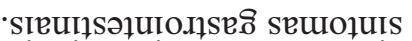

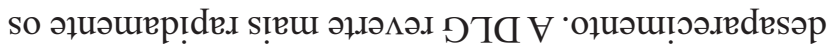

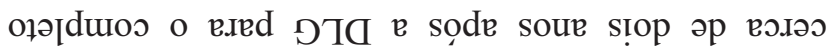

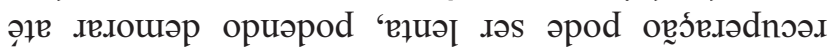

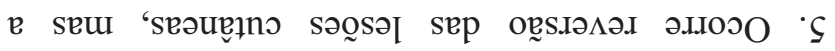

'se e оилорә о шоэ 'шәдо

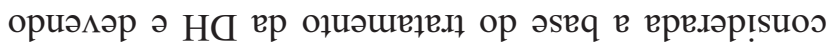

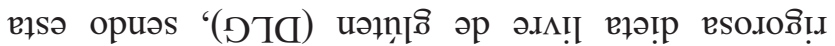

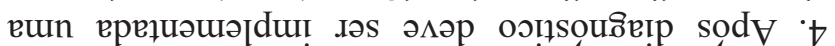

'seร́นวор se ว.ұนว

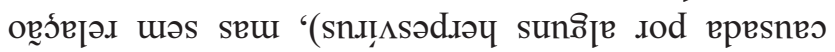

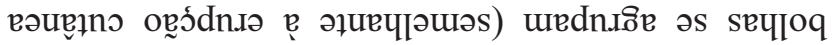

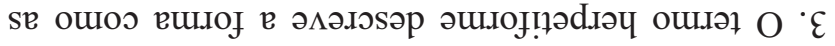

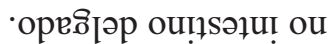

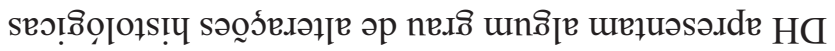

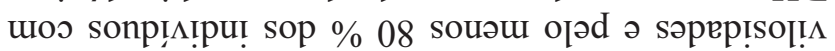

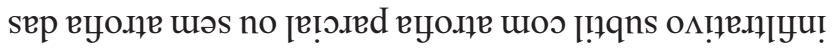

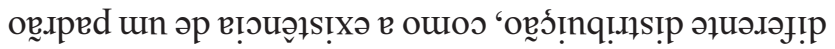

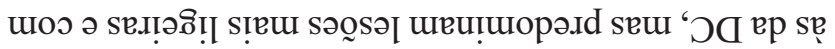

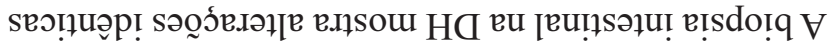

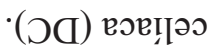

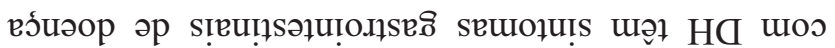

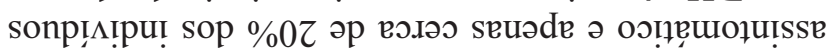

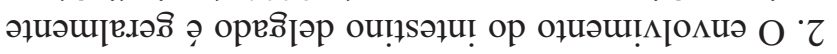

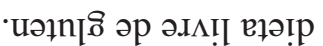

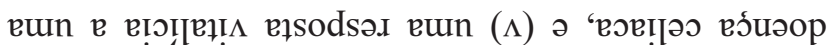

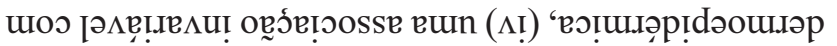

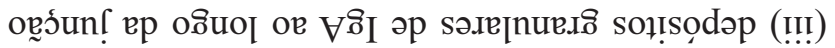

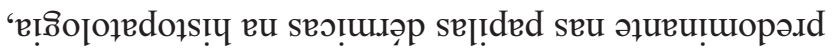

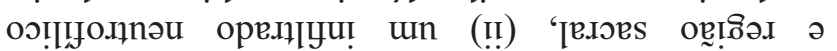

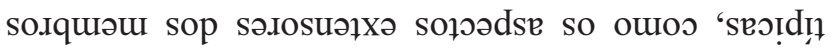

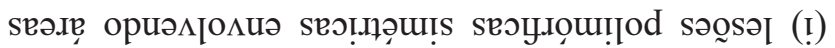

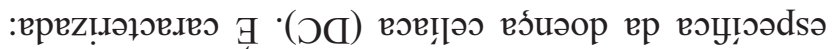

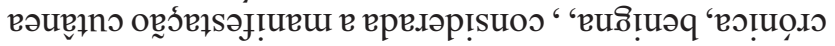

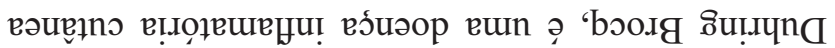

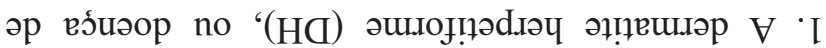

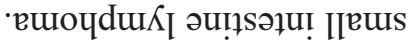

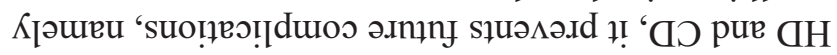

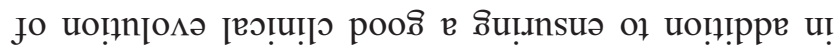

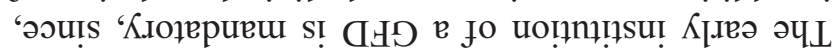

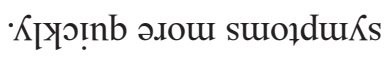
[ยน!ฺ

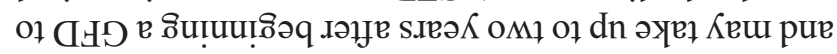

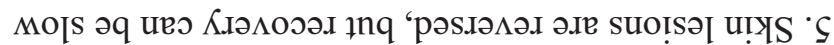

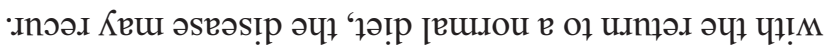

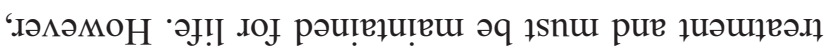

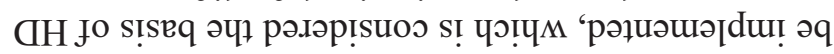

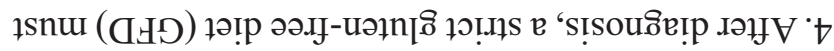

'səseəs!̣p ә૫Р иәәмұәq d!̣

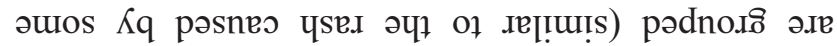

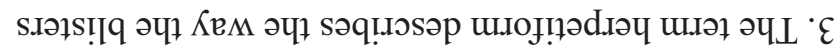

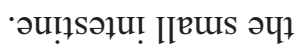

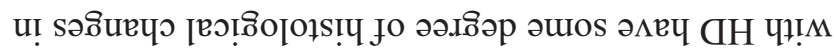

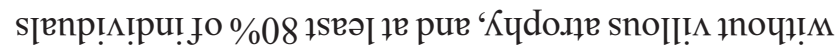

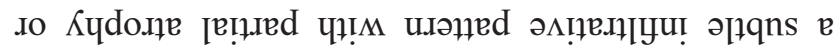

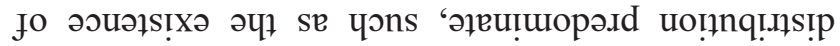

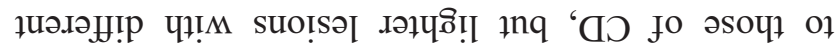

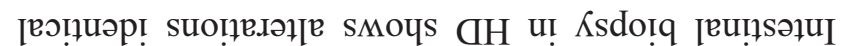

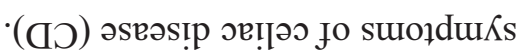

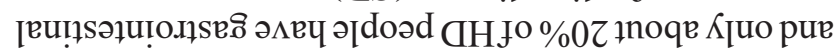

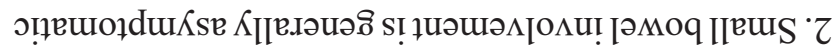

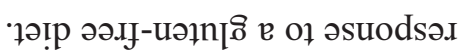

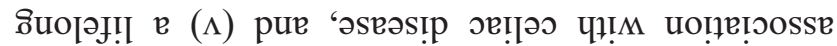

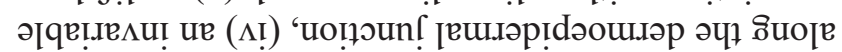

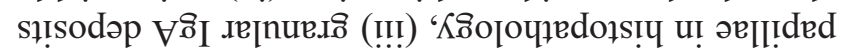

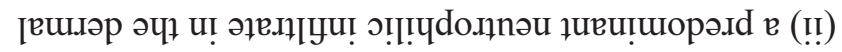

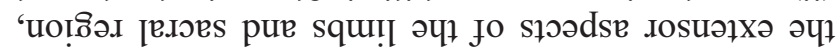

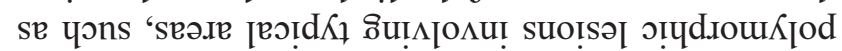

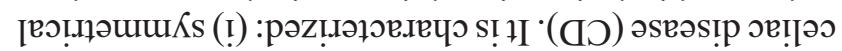

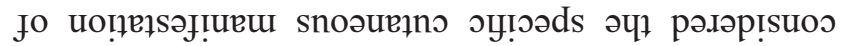

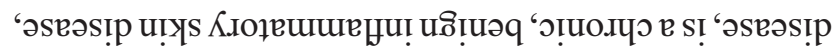

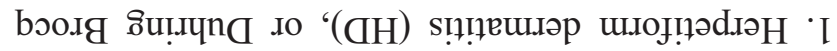




\section{References / Referências}

1. Reunala, T., Salmi, T. T., Hervonen, K., Kaukinen, K., \& Collin, P. (2018). Dermatitis Herpetiformis: A Common Extraintestinal Manifestation of Coeliac Disease. Nutrients, 10(5), 602. https://doi.org/10.3390/nu100506022.

2. Caproni, M., Antiga, E., Melani, L., Fabbri, P., \& Italian Group for Cutaneous Immunopathology (2009). Guidelines for the diagnosis and treatment of dermatitis herpetiformis. Journal of the European Academy of Dermatology and Venereology : JEADV, 23(6), 633-638. https://doi.org/10.1111 /j.1468-3083.2009.03188.x2

3. Antiga, E., Maglie, R., Quintarelli, L., Verdelli, A., Bonciani, D., Bonciolini, V., \& Caproni, M. (2019). Dermatitis Herpetiformis: Novel Perspectives. Frontiers in immunology, 10, 1290. https://doi.org/10.3389/fimmu.2019.01290 